\title{
Effect of iron dextran, gold thiosulphate, and hydrocortisone acetate on experimental synovitis in the guinea-pig
}

\author{
A. G. MOWAT,* T. F. DISNEY, $\dagger$ AND J. H. VAUGHAN $\dagger$ \\ From the Department of Medicine, University of Rochester School of Medicine and Dentistry, Rochester, \\ New York, U.S.A.
}

Considerable controversy has revolved about the nature of the disturbed iron metabolism in patients with rheumatoid arthritis and the question whether the depositions of iron in the synovial tissues of these patients represent beneficial or harmful events (Mowat and Hothersall, 1968). Lawson, Owen, and Mowat (1967) showed that there was an increase in the urinary excretion of iron in patients with rheumatoid arthritis compared with controls after the administration of the chelating agent desferrioxamine B. It was considered that these results provided evidence of increased iron storage in these patients. Subsequently Mowat and Hothersall (1968) and Senator and Muirden (1968) showed considerably higher concentrations of iron in the synovial tissue of patients with rheumatoid arthritis compared with controls. Since there is proliferation of the synovial tissue in these patients, relatively large quantities of iron could be deposited in this tissue. The iron is present in the synovial tissue in the form of ferritin and has a distinctive appearance under light or electron microscopy (Muirden, 1966). A similar increase in the quantity of ferritin and in its distribution to that found in patients with rheumatoid arthritis has been noted in experimental arthritis induced in rabbits with caragheenin, Freund's adjuvant, and tuberculin (Muirden and Peace, 1969). Muirden (1966, 1970) and Muirden, Fraser, and Clarris (1967) suggested that the ferritin was deposited in the synovial tissue as the end-result of repeated small haemorrhages and subsequent erythrophagocytosis by the synovial lining cells.

This mechanism could possibly explain the findings in rheumatoid arthritis as red blood cells in small numbers can be found in many joint effusions in these patients. However, it is less easily invoked as the mechanism involved in the experimental arthritides which are of short duration.
A reduced clearance of $\mathbf{F e}^{59}$-labelled erthrocytes from the knee joints of rabbits with caragheenin arthritis compared with controls (Muirden, 1969) with subsequent deposition of iron in the synovial tissue has been described (Muirden, Peace, and Rogers, 1969). This confirms the work of Roy and Ghadially (1966), who demonstrated the ability of rabbit synovial tissue to form ferritin from erythrocytes, and of Muirden and others (1967), who showed the formation of ferritin by human synovial cells in culture on exposure to haemoglobin. However, it is possible that the iron might reach the synovial tissue by transfer from the plasma or synovial fluid. The presence of a low serum iron level and an equally low synovial fluid iron (Senator and Muirden, 1966; personal observations) does not exclude the possibility of an iron gradient. Rabbit synovial tissue has also been shown to form ferritin from iron-dextran (Ball, Chapman, and Muirden, 1964). Thus it is clear that synovial tissue has the capacity to form ferritin from haemoglobin or elemental iron, but the source of the iron has not been determined.

Muirden (1966) and Muirden and others (1969) have suggested that the presence of iron in the synovial tissue might be harmful and might lead to the release of lysosomal enzymes, resulting in damage to the joint. There is no evidence for this mechanism. In addition, iron stored in the synovial tissue in haemochromatosis is not the cause of the associated arthropathy, which is essentially degenerative in nature (Hamilton, Williams, Barlow, and Smith, 1968; Wardle and Patton, 1969). Richmond, Roy, Gardner, Alexander, and Duthie (1958) showed that a $5 \mathrm{~g}$. course of saccharated oxide of iron, given intravenously to patients with rheumatoid arthritis, was followed not only by an increase in the haemoglobin concentration but also by a

\footnotetext{
Based on a paper given at a meeting of the Heberden Society in Edinburgh on September 25, 1970. 
reduction in the erythrocyte sedimentation rate and in the activity of the disease and by an improvement in the functional capacity of the patient. It seems possible, therefore, that the iron in the synovial tissue could be derived from the plasma and might exercise a beneficial rather than harmful effect.

The present investigation was designed to test in an experimental synovitis in guinea-pigs whether in fact iron was harmful or beneficial and to compare the effect of iron with known anti-inflammatory agents.

\section{Material and methods}

An acute synovitis, which persisted if untreated for over 7 days, was induced in one elbow joint of 3 to $400 \mathrm{~g}$. guinea-pigs by the intra-articular injection of the polyene antibiotic Nystatin (10,000 i.u. in $0.1 \mathrm{ml}$. physiological saline) (Weissmann, Pras, and Rosenberg, 1967). The synovitis did not appear to be accompanied by any systemic reaction. This synovitis was used as a model in which to test the effect of intra-articular injections of various drugs with proved or possible anti-inflammatory activity. Since it was found in initial experiments that slightly better control of the synovitis was achieved by injecting the test substances $24 \mathrm{hrs}$ before the Nystatin compared to 24 hrs after the Nystatin, this timetable was used throughout the study.

One elbow joint of the guinea-pigs was injected with iron-dextran (Imferon) in a concentration containing 100 or $200 \mu \mathrm{g}$. elemental iron; or gold thiosulphate in a concentration containing 200 or $\mathbf{4 0 0} \mu \mathrm{g}$. elemental gold; or $250 \mu \mathrm{g}$. hydrocortisone acetate. All the test materials were made up in $0.1 \mathrm{ml}$. physiological saline. Five to ten animals were used to assess the effect of each test material. Four animals were injected intra-articularly with Dextran (M.W. 8000) in the same concentration as in iron-dextran $(200 \mu \mathrm{g}$.) made up in $0 \cdot 1 \mathrm{ml}$. physiological saline. $24 \mathrm{hrs}$ later synovitis was induced in the same elbow joint by Nystatin and the subsequent progress of the inflammation was followed. Control animals were injected with Nystatin alone. In addition control studies were undertaken to ensure the similarity of the two elbow joints and that the injections of iron-dextran, gold thiosulphate, hydrocortisone acetate, and physiological saline in the same volume did not cause synovitis or alter the characteristics of the joint.

Further studies were undertaken to assess the effect of intramuscular injections of iron-dextran on the Nystatininduced synovitis. Synovitis was induced in one elbow joint of eight guinea-pigs in the same manner as described above 1 day after doses of iron-dextran containing $5 \mathrm{mg}$. elemental iron had been injected into the thigh muscles. In a further eighteen animals the synovitis was induced 1 to 15 days after doses of iron-dextran containing 2.5 to $10 \mathrm{mg}$. elemental iron had been injected into the thigh muscles. An attempt was made to correlate the degree of synovitis 1 and 2 days after the injection of Nystatin with the plasma iron level of the animals. Blood was drawn by intracardiac puncture on the first day of joint assessment. Plasma iron values were measured by the method of Ramsay (1957). The usual precautions to avoid iron contamination of the glass-ware were observed.
The synovitis was assessed by the use of an external counting method after the intravenous injection of radioactive $I^{131}$ human serum albumin (RISA) (Mowat, Disney, and Vaughan, 1970). The result, which is chiefly a measure of joint vascularity, was expressed as the ratio

\section{Counts per minute from the injected joint Counts per minute from the non-injected joint $\times 100$}

On this basis a value of 100 signifies no detectable inflammation. A clinical assessment of the synovitis was also carried out, but since in the earlier study (Mowat and others, 1970) this had not been shown to be as accurate as the external counting method the results are not included. The synovitis was measured at daily intervals after the injection of Nystatin for up to 7 days in those animals receiving Nystatin alone, but 4 days proved to be sufficient in those animals receiving the test injections. For the control studies external counting was carried out at 6 and $24 \mathrm{hrs}$ after the test injections.

\section{Results}

Intra-articular injections of iron-dextran $(200 \mu \mathrm{g}$. elemental iron), gold thiosulphate ( $400 \mu \mathrm{g}$. elemental gold), and $250 \mu \mathrm{g}$. hydrocortisone acetate in $0 \cdot 1 \mathrm{ml}$. physiological saline, and of $0 \cdot 1 \mathrm{ml}$. physiological saline alone did not produce synovitis. The results for the degree of synovitis produced by intraarticular injections of Nystatin alone, and by Nystatin $24 \mathrm{hrs}$ after intra-articular injections of iron-dextran (100 and $200 \mu \mathrm{g}$. elemental iron), gold thiosulphate (200 and $400 \mu \mathrm{g}$. elemental gold), hydrocortisone acetate $(250 \mu \mathrm{g}$.), and by Nystatin $24 \mathrm{hrs}$ after intramuscular injections of iron-dextran ( $5 \mathrm{mg}$. elemental iron) are set out in Table I. These results, expressed as the ratio of radioactivity, which equals

$\frac{\text { counts per minute from the injected joint }}{\text { counts per minute from the non-injected joint }} \times 100$

after subtraction of the background radioactivity, are the mean values \pm 1 SD for five to ten animals at daily intervals after the injection of Nystatin.

In those joints injected with Nystatin alone, the synovitis slowly settled from a mean value of 241 on Day 1 to 118 on Day 7.

All test substances produced a striking control of the synovitis with values that were significantly less $(P<0.0005)$ on each of the 4 days after the injection of Nystatin. In every case only minimal synovitis remained on the 4th day.

The effect of the intra-articular injection of irondextran $(200 \mu \mathrm{g}$.) was not significantly different than that of gold thiosulphate $(400 \mu \mathrm{g}$.) $(P<0 \cdot 20)$ but was greater than that of any of the other injections.

The effect of iron-dextran $(100 \mu \mathrm{g}$.) was intermediate between the effects of the two injections of gold thiosulphate. It would appear from these 
Table I Effect of iron dextran, gold thiosulphate, and hydrocortisone on Nystatin-induced synovitis

\begin{tabular}{|c|c|c|c|c|c|c|c|c|c|}
\hline \multirow[t]{2}{*}{ Route } & \multirow[t]{2}{*}{ Agent } & \multirow[t]{2}{*}{$\begin{array}{l}\text { Number of } \\
\text { animals }\end{array}$} & \multirow{2}{*}{$\begin{array}{l}\text { Mean } \\
\text { joints }> \\
\text { (Days } \\
1\end{array}$} & $\begin{array}{l}\text { ratios of } \\
<100 \pm \\
\text { after indu }\end{array}$ & \multicolumn{4}{|c|}{$\begin{array}{l}\text { radioactivity between injected and } \\
1 \text { S.D. } \\
\text { ction of synovitis by Nystatin) }\end{array}$} & \multirow{2}{*}{$\begin{array}{l}\text { non-injected } \\
\overline{7}\end{array}$} \\
\hline & & & & 2 & 3 & 4 & 5 & 6 & \\
\hline \multirow[t]{6}{*}{$\begin{array}{l}\text { Intra- } \\
\text { articular }\end{array}$} & Nystatin & 8 & $\begin{array}{l}241 \\
\pm 36\end{array}$ & $\begin{array}{l}195 \\
\pm 30\end{array}$ & $\begin{array}{l}182 \\
\pm 24\end{array}$ & $\begin{array}{l}151 \\
\pm 11\end{array}$ & $\begin{array}{l}127 \\
\pm 10\end{array}$ & $\begin{array}{l}126 \\
\pm 9\end{array}$ & $\begin{array}{l}118 \\
\pm 5\end{array}$ \\
\hline & $\begin{array}{l}200 \mu \mathrm{gg} \text {. iron-dextran } \\
\text { : Nystatin }\end{array}$ & 9 & $\begin{array}{l}136 \\
\pm 21\end{array}$ & $\begin{array}{r}114 \\
\pm 7\end{array}$ & $\begin{array}{l}105 \\
\pm 5\end{array}$ & $\begin{array}{l}103 \\
\pm 4\end{array}$ & & & \\
\hline & $\begin{array}{l}100 \mu \mathrm{g} \text {. iron-dextran } \\
: \text { Nystatin }\end{array}$ & 8 & $\begin{array}{l}154 \\
\pm 28\end{array}$ & $\begin{array}{l}125 \\
\pm 12\end{array}$ & $\begin{array}{l}112 \\
\pm 4\end{array}$ & $\begin{array}{l}106 \\
\pm 2\end{array}$ & & & \\
\hline & $\begin{array}{l}400 \mu \mathrm{g} . \text { gold } \\
\text { thiosulphate } \\
: \text { Nystatin }\end{array}$ & 9 & $\begin{array}{l}143 \\
\pm 24\end{array}$ & $\begin{array}{l}114 \\
\pm 10\end{array}$ & $\begin{array}{r}108 \\
\pm 6\end{array}$ & $\begin{array}{l}105 \\
\pm 6\end{array}$ & & & \\
\hline & $\begin{array}{l}200 \mu \mathrm{g} . \text { gold } \\
\text { thiosulphate } \\
: \text { Nystatin }\end{array}$ & 5 & $\begin{array}{l}162 \\
\pm 26\end{array}$ & $\begin{array}{l}127 \\
\pm 10\end{array}$ & $\begin{array}{l}117 \\
\pm 5\end{array}$ & $\begin{array}{r}110 \\
\pm 4\end{array}$ & & & \\
\hline & $\begin{array}{l}\text { Hydrocortisone acetate } \\
250 \mu \mathrm{g} \text {. : Nystatin }\end{array}$ & 10 & $\begin{array}{l}151 \\
\pm 37\end{array}$ & $\begin{array}{l}124 \\
\pm 12\end{array}$ & $\begin{array}{l}112 \\
\pm 4\end{array}$ & $\begin{array}{l}107 \\
\pm 4\end{array}$ & & & \\
\hline $\begin{array}{l}\text { Intra- } \\
\text { muscular }\end{array}$ & $\begin{array}{l}5 \mathrm{mg} \text {. iron dextran } \\
\text { : Nystatin }\end{array}$ & 8 & $\begin{array}{l}169 \\
\pm 21\end{array}$ & $\begin{array}{l}128 \\
\pm 14\end{array}$ & $\begin{array}{l}113 \\
\pm 4\end{array}$ & $\begin{array}{l}106 \\
\pm 4\end{array}$ & & & \\
\hline
\end{tabular}

results that iron is approximately twice as effective as gold, on the basis of elemental weight, in controlling the synovitis induced by Nystatin. There were no significant differences between the effects of irondextran $(100 \mu \mathrm{g}$.), intramuscular iron-dextran ( $5 \mathrm{mg}$.), and hydrocortisone acetate $(250 \mu \mathrm{g}$.).

Dextran alone, in the same concentration as used in iron-dextran $(200 \mu \mathrm{g}$.), had no effect on the synovitis.

Table II shows the degree of synovitis in eighteen animals 1 and 2 days after the intra-articular injection of Nystatin. These animals had previously been injected with varying doses of iron-dextran intramuscularly and the values for the degree of synovitis are compared with the plasma iron value estimated on blood drawn on Day 1. No correlation between the degree of control of the synovitis and the plasma iron value could be demonstrated (Correlation coefficient Day 10.3559 ; Day 2 0.3003).

In only five animals was the plasma iron value greater than the mean normal plasma iron value determined on blood drawn from five animals untreated with either Nystatin or iron-dextran of $562 \mu$ g. per cent.

\section{Discussion}

These results support the suggestion of Richmond and others (1958) that iron has a beneficial effect on synovial inflammation. There was significant control
Table II Comparison of plasma iron values and radioactive assessment of synovitis in eighteen animals

\begin{tabular}{llll}
\hline $\begin{array}{l}\text { Animal } \\
\text { number }\end{array}$ & $\begin{array}{l}\text { Plasma } \\
\text { iron } \\
\mu g . \text { per cent }\end{array}$ & $\begin{array}{l}\text { Ratio of radioactivity } \\
\text { (Days after induction of } \\
\text { synovitis) }\end{array}$ \\
\cline { 2 - 4 } & & 1 & 2 \\
\hline 1 & 400 & 181 & 128 \\
2 & 350 & 231 & 171 \\
3 & 408 & 162 & 138 \\
4 & 843 & 150 & 117 \\
5 & 1317 & 145 & 127 \\
6 & 475 & 206 & 131 \\
7 & 408 & 185 & 123 \\
8 & 441 & 127 & 131 \\
9 & 697 & 166 & 138 \\
10 & 246 & 170 & 131 \\
11 & 367 & 159 & 113 \\
12 & 3517 & 118 & 133 \\
13 & 834 & 148 & 129 \\
14 & 346 & 174 & 113 \\
15 & 363 & 114 & 104 \\
16 & 246 & 144 & 131 \\
17 & 453 & 121 & \\
18 & 433 & 133 & \\
& & &
\end{tabular}

of Nystatin-induced synovitis in guinea-pig elbow joints when iron was administered by either intraarticular or intramuscular injection. The effect of the iron, administered as iron-dextran, was shown not to be due to the Dextran. In addition, on the basis of elemental weight, iron was approximately twice 
as effective as gold in controlling synovitis in our system. Further, $100 \mu \mathrm{g}$. iron had the same effect as $250 \mu \mathrm{g}$. hydrocortisone acetate.

The failure to demonstrate a direct relationship between the degree of control of the synovitis and the plasma iron value was disappointing. This probably reflects differences in the rates of uptake by the synovial tissue, of transfer from the plasma to the synovial fluid, of removal from the injection site, and of urinary excretion of the iron. In all but five cases the plasma iron value was lowered from the normal value as occurs in active rheumatoid arthritis (Nilsson, 1948). This suggests that there is an active removal of iron from the plasma in these animals and that some control of the synovitis occurs if increased iron is made available to them.

Nystatin and the other polyene antibiotics are considered to cause inflammation by the release of lysosomal enzymes and the effect is not specific for synovial tissue (Weissmann and others, 1967). Weissmann, Spilberg, and Krakauer (1969) have also shown that lysates of polymorphonuclear leucocytes produce a similar synovitis to that induced by Nystatin in studies of experimental synovitis in rabbits, and it has been postulated that the release of these lysosomal enzymes is the final pathway in any form of synovitis (Weissmann, 1966). The mechanism by which iron achieves its effect has not been determined. Hydrocortisone has generally been believed to be a stabilizer of lysosomal membranes (de Duve, Wattiaux, and Wibo, 1962; Weissmann, 1965), although Hempel, Fernandez, and Persellin (1970) failed to demonstrate a protective effect when isolated rabbit leucocyte lysosomes were stressed by detergent in the presence of hydrocortisone. Weissmann and others (1967) were also able to reduce the effect of intra-articular injections of the polyene antibiotics in rabbit knee-joints by prior intraarticular injection of cortisone acetate. Intraarticular injections of gold salts have been shown to have a beneficial local effect on the synovitis of rheumatoid arthritis (Lewis and Ziff, 1966). Gold salts have been shown to inhibit lysosomal enzymes after their release (Persellin and Ziff, 1966; Ennis, Granda, and Posner, 1968; Paltenaa, 1968). Further studies will be required to see if iron may act in a related manner either by preventing the release of lysosomal enzymes or by inhibiting the enzymes after their release.

Masson, Heremans, and Schonne (1969) have shown that polymorphonuclear leucocytes contain lactoferrin. This is an iron-binding protein similar to but chemically and antigenically different from transferrin. Lactoferrin has a stronger avidity for iron than transferrin, and this difference is enhanced in an acid pH (Masson and others, 1969) which is present in inflammatory joint lesions (Goldie and
Nachemson, 1969). This ability of the polymorphonuclear leucocyte to bind iron may explain the findings in this study and some of the abnormalities in iron metabolism in rheumatoid arthritis.

The presence of iron in the polymorphonuclear leucocyte could allow an effect on lysosomal granules to occur, and lactoferrin has been identified in the specific or secondary granules of rabbit neutrophil leucocytes (Baggiolini, de Duve, Masson, and Heremans, 1970). The deposition of iron in the synovial lining cells, particularly those with macrophage properties, in rheumatoid arthritis (Muirden, 1966) could result from the ingestion of iron-loaded degenerate polymorphonuclear leucocytes. The combination of tissue deposition and the increased concentration of iron in the polymorphonuclear leucocytes at the expense of transferrin could explain the low plasma iron and the normal plasma ironbinding capacity in rheumatoid arthritis.

The reticuloendothelial system, of which the phagocytic lining cells of the synovial membrane can be considered a part, may take up iron directly from the synovial fluid or plasma, without the need to postulate the polymorphonuclear leucocyte as an intermediate step. Many tissues have the capacity to form apoferritin in the presence of iron and hence to produce ferritin (Gabrio and Salomon, 1950).

It is a matter of speculation whether, on the basis of the effects of iron administered by intra-articular or intramuscular injection on an acute, self-limiting synovitis in guinea-pigs, this method of therapy should be tried or even be expected to be effective in rheumatoid arthritis. Richmond and others (1958) showed that a $5 \mathrm{~g}$. course of saccharated oxide of iron given intravenously had a beneficial effect on the synovitis in patients with rheumatoid arthritis, and a $3 \mathrm{~g}$. course of intravenous iron is commonly employed by some physicians (Duthie, 1967). These doses are far in excess of those calculated to correct the anaemia in these patients. Lewis and Ziff (1966) have shown that gold salts, which are established anti-inflammatory agents in rheumatoid arthritis, have a local effect when administered intra-articularly. Ball and others (1964) found that iron-dextran caused a transient synovitis when injected intraarticularly into rabbits, but the doses employed were much larger than those used in this study. We found no evidence of a transient synovitis in our guineapigs.

Reddy and Lewis (1969) and Lloyd and Williams (1970) have noted an exacerbation of joint symptoms in patients with rheumatoid arthritis treated with iron-dextran by the total dose infusion technique, although there are no reports of similar reactions when the iron-dextran has been given in the form of a course of intravenous or intramuscular injections. Lloyd and Williams (1970) suggest that this is due to 
a delayed hypersensitivity reaction to the Dextran. It is possible that this reaction to iron-dextran represents the Auer phenomenon (Auer, 1920), in which antigen-antibody complexes can be shown to accumulate at the site of pre-existing inflammation and to exacerbate this inflammation. Species differences may also account for the favourable response and absence of adverse reactions found in guineapigs.

From the evidence presented here it seems reasonable to postulate that the accumulation of iron in the synovial tissue of patients with rheumatoid arthritis does not cause tissue damage by the release of lysosomal enzymes (Muirden, 1966). Indeed, it is suggested that the iron has a beneficial effect. Future studies will be needed to show whether the iron is deposited in the synovial tissue as an active process rather than as an end-result of either erythrophagocytosis following repeated small haemorrhages into the synovial fluid (Muirden, 1966, 1970) or phagocytosis of iron-loaded neutrophils as suggested above.

\section{Summary}

An acute, self-limiting synovitis has been induced in one elbow joint of guinea-pigs by the intra-articular injection of Nystatin. The effects on this synovitis of intra-articular injections of iron-dextran, gold thiosulphate, and hydrocortisone acetate, and of intra-muscular injections of iron-dextran have been compared, using an external counting technique after the intravenous injection of radio-iodinated (I131) human serum albumin.

Iron was found to be approximately twice as effective as gold in controlling the synovitis on the basis of elemental weight. Intra-articular injections of $100 \mu \mathrm{g}$. iron and $250 \mu \mathrm{g}$. hydrocortisone acetate and intramuscular injections of $5 \mathrm{mg}$. iron were found to have the same controlling effect on the synovitis.

These results are discussed in the light of the known deposition of iron in the synovial membrane of patients with rheumatoid arthritis. The mechanisms by which iron could accumulate in the synovial tissue in these patients and its probable beneficial effect are also discussed.

We wish to thank Prof. P. Rubin, Radiotherapy Department, University of Rochester, New York, U.S.A., for the supplies of radioactive $\left(\mathbf{I}^{131}\right)$ human serum albumin and for the use of the Picker Magna-scanner.

This work was supported by U.S.P.H.S. grants AM- 02443 and A1-28.

During the period of this study A.G.M. was in receipt of a travel grant from the Arthritis and Rheumatism Council, T.F.D. was in receipt of a fellowship and training grant from the Medical Research Council of
Canada, and J.H.V. was the recipient of a Research Career Award from the National Institutes of Health.

\section{Discussion}

DR. D. L. GARDNER (London) What is the analogy between Nystatin arthritis and rheumatoid arthritis? How closely similar is it in its clinical and pathological appearances? Your assessment of the inflammatory response is based on the apparent permeability of blood vessels to iodinated human albumin. Could there be any difference between the response to iodinated guinea-pig albumin? Were you able to use this?

DR. MOWAT We did not use iodinated guinea-pig albumin because it was not readily available. We did some work to see where the albumin was going, and it seemed to act chiefly as a vascular marker, although about 10 per cent. of the activity was contributed by the synovial fluid and interstitial fluid.

As regards its relationship to rheumatoid arthritis, it seemed to be simply a self-limiting, acute, proliferative response. Weissmann, Pras, and Rosenberg (1967) used repeated injections of these antibiotics into joints and produced a chronic arthritis which they claimed is very like rheumatoid arthritis.

PROF. E. G. L. BYWATERS (London) Have you controlled these experiments by injecting saline (to exclude the non-specific effect of distension) and by injecting these various substances into the opposite joint?

DR. MOWAT I think most of these controls have been done. We have certainly used saline and we used another obvious control, Dextran alone, which had no effect. I have not tried the effect of putting the materials into the opposite elbow joint, but this study did include the use of intramuscular injection of iron, so I think we are dealing with something specific.

PROF. J. J. R. DUTHIE (Edinburgh) We have used intravenous iron for many years now and have been very satisfied with both the haematological and clinical effects. We give $200 \mathrm{mg}$. daily, 5 days a week, for 2 or 3 weeks. I saw recently a paper suggesting that iron was bad for rheumatoid joints, but the authors concerned gave a continuous infusion, which is entirely different from intermittent administration over a period of weeks. I think we should not accept this harmful effect at its face value if it is going to deprive patients of what we find to be a very useful form of treatment. I think that Dr. Mowat himself found that too large an intramuscular injection of iron produced a violent synovial reaction which subsided in a day or two. We got the impression that ultimately this joint was quieter than before. Perhaps too much iron locally (from any cause) exacerbates the condition. The other point I would like to make is that, if you give ACTH (without administration of iron), there is a rapid rise in the serum iron. In other words, suppression of the inflammatory process alone appears to release this iron. This is against the idea that iron accumulates because of small haemorrhages. If that were so, why should suppressing the inflammation release it? 
I think it is active in the presence of active inflammation and that it is released from that site if the inflammation is suppressed.

DR. C. F. HAWKINS (Birmingham) Are you suggesting that the anaemia of rheumatoid arthritis differs from the anaemia of other chronic infections and inflammations in which the serum iron becomes low, and do you think that the mechanism of disappearance of iron from the plasma is different? Would it not go to the reticuloendothelial system in rheumatoid patients as in those with other inflammatory diseases?

I have always been impressed with this excellent work in Edinburgh on the use of intravenous iron in rheumatoid arthritis, and I wonder whether it has been confirmed by other workers. (I do not doubt that the Edinburgh findings are true.) Finally, in the anaemia of chronic infections, does intravenous iron also reduce the inflammation, judging by other criteria such as the erythrocyte sedimentation rate?

DR. MOWAT I am sure that the anaemia of rheumatoid arthritis must be closely related to that seen in chronic infections, but there is some difference in that in rheumatoid arthritis there is what amounts to an extension of the reticuloendothelial system into the joints. We have reported large quantities of iron in this synovial tissue (Mowat and Hothersall, 1968). I think the position is somewhat exaggerated in rheumatoid arthritis; not only is the reticuloendothelial system enlarged, but there is also a lot of proliferative tissue doing much the same thing. I am sure that the mechanism is probably very similar and the recent work on lactoferrin (Baggiolini and others, 1970) suggests a common pathway by which this could happen. This material, which binds iron better than transferrin in inflammatory exudates and subsequently into the reticuloendothelial system, helps to explain why there is a low plasma iron value but a normal plasma iron-binding capacity, because the transferrin has not been increased. I am not aware that other workers have substantiated the claims from Edinburgh about the anti-inflammatory effect of saccharated oxide of iron; they appear to have taken it on trust. I am not aware that anyone has tested this material in anaemia of chronic infections; they are probably more concerned with treating the particular infection.

\section{References}

AUER, J. (1920) J. exp. Med., 32, 427 (Local autoinoculation of the sensitized organism with foreign protein as a cause of abnormal reactions).

Bagglolini, M., de Duve, C., Masson, P. L., and Heremans, J. F. (1970) Ibid., 131, 559 (Association of lactoferrin with specific granules in rabbit heterophil leukocytes).

Ball, J., Chapman, J. A., AND Muirden, K. D. (1964) J. Cell Biol., 22, 351 (The uptake of iron in rabbit synovial tissue following intra-articular injection of iron dextran).

DuthIE, J. J. R. (1967) Scot. med. J., 12, 96 (Medical management and prognosis in rheumatoid arthritis).

De Duve, C., WattiauX, R., AND WiBo, M. (1962) Biochem. Pharmacol., 9, 97 (Effects of fat-soluble compounds on lysosomes in vitro).

EnNis, R. S., Granda, J. L., AND Posner, A. S. (1968) Arthr. and Rheum., 11, 756 (Effect of gold salts and other drugs on the release and activity of lysosomal hydrolases).

Gabrio, B. W., and Salomon, K. (1950) Proc. Soc. exp. Biol (N.Y.), 75, 124 (Distribution of total ferritin in intestine and mesenteric lymph nodes of horses after iron feeding).

Goldie, I., AND NaChemson, A. (1969) Acta orthop. scand., 40, 634 (Synovial pH in rheumatoid knee joints. 1. The effect of synovectomy).

Hamilton, E., Williams, R., Barlow, K. A., AND Smith, P. M. (1968) Quart. J. Med., n.s. 37, 171 (Arthropathy of idiopathic haemochromatosis).

Hempel, K. H., Fernandez, L. A., And Persellin, R. H. (1970) Nature (Lond.), 225, 955 (Effect of pregnancy sera on isolated lysosomes).

Lawson, A. A. H., Owen, E. T., AND Mowat, A. G. (1967) Ann. rheum. Dis., 26, 552 (Nature of anaemia in rheumatoid arthritis. VII. The storage of iron in rheumatoid disease).

LEwis, D. C., AND ZIFF, M. (1966) Arthr. and Rheum., 9, 682 (Intra-articular administration of gold salts).

Lloyd, K. N., AND Williams, P. (1970) Brit. med. J., 2, 323 (Reactions to total dose infusion of iron dextran in rheumatoid arthritis).

Masson, P. L., Heremans, J. F., ANd Schonne, E. (1969) J. exp. Med., 130, 643 (Lactoferrin, an iron-binding protein in neutrophil leukocytes).

Mowat, A. G., Disney, T. F., AND Vaughan, J. H. (1971) Ann. rheum. Dis., 30, 183 (Articular scanning and external counting in experimental arthritis in the guinea-pig).

- AND Hothersall, T. E. (1968) Ibid., 27, 345 (Nature of anaemia in rheumatoid arthritis. VIII. Iron content of synovial tissue in patients with rheumatoid arthritis and in normal individuals).

MuIRDEN, K. D. (1966) Ibid., 25, 387 (Ferritin in synovial cells in patients with rheumatoid arthritis).

- (1969) Ibid., 28, 548 (Clearance of $\mathrm{Fe}^{59}$-labelled erythrocytes from normal and inflamed rabbit knee joints. I. Relationship to the anaemia of rheumatoid arthritis).

(1970) Ibid., 29, 81 (Lymph node iron in rheumatoid arthritis. Histology, ultrastructure, and chemical concentration).

—, Fraser, J. R. E. AND Clarris, B. (1967) Ihid . 26, 251 (Ferritin formation by synovial cells exposed to haemoglobin in vitro). 
- AND PeACE, G. (1969) Ibid., 28, 392 (Light and electron microscope studies in caragheenin, adjuvant and tuberculin-induced arthritis).

- _ - AND ROGERS, K. (1969) Ibid., 28, 630 (Clearance of Fe 59 -labelled erythrocytes from normal and inflamed rabbit knee joints. II. Autoradiographic \& histological studies).

Nilsson, F. (1948) Acta med. scand., 130, Suppl. 210 (Anaemia problems in rheumatoid arthritis).

PaltemaA, S. (1968) Acta rheum. scand., 14, 161 (The inhibition of lysosomal enzymes by gold salts in human synovial fluid cells).

Persellin, R. H., AND ZifF, M. (1966) Arthr. and Rheum., 9, 57 (The effect of gold salt on lysosomal enzymes of the peritoneal macrophage).

Ramsay, W. N. M. (1957) Clin. chim. Acta, 2, 214 (Determination of iron in blood plasma or serum).

ReDDy, P. S., AND LEWIS, M. (1969) Arthr. and Rheum., 12, 454 (The adverse effect of intravenous iron-dextran in rheumatoid arthritis).

Richmond, J., Roy, L. M. H., Gardner, D. L., Alexander, W. R. M., and Duthie, J. J. R. (1958) Ann. rheum. Dis., 17, 406 (Nature of anaemia in rheumatoid arthritis. IV. Effects of the intravenous administration of saccharated oxide of iron).

Roy, S., AND Ghadially, F. N. (1966) Ibid., 25, 402 (Pathology of experimental haemarthrosis).

SeNATOR, G. B., AND MUIRDEN, K. D. (1968) Ibid., 27, 49 (Concentration of iron in synovial membrane, synovial fluid and serum in rheumatoid arthritis and other joint diseases).

Wardle, E. N., and Patton, J. T. (1969) Ibid., 28, 15 (Bone and joint changes in haemochromatosis).

Weissmann, G. (1965) Biochem. Pharmacol., 14, 525 (Studies of lysosomes. VI. The effects of neutral steroids and bile acids on lysosomes in vitro). (1966) Arthr. and Rheum., 9, 834 (Lysosomes and joint disease). , Pras, M., and Rosenberg, L. (1967) Ibid., 10, 325 (Arthritis induced by filipin in rabbits).

-, SPILBERG, I., AND KRAKAUER, K. (1969) Ibid., 12, 103 (Arthritis induced in rabbits by lysates of granulocyte lysosomes). 